\title{
INNOWACYJNOŚĆ POLSKICH PRZEDSIĘBIORSTW NA RYNKU SUPLEMENTÓW DIETY W POLSCE W KONTEKŚCIE STRATEGII EUROPA 2020
}

DOI: $10.33141 /$ po. 2020.04.02

Marta Hrydziuszko, Grzegorz Chodak
Przegląd Organizacji, Nr 4(963), 2020, s. 12-22 www.przegladorganizacji.pl ๑ Towarzystwo Naukowe Organizacji i Kierownictwa (TNOiK)

\section{Wprowadzenie}

$\mathrm{U}$

nia Europejska zwraca szczególną uwagę na innowacyjną działalność przedsiębiorstw, która przekłada się na wyniki gospodarki państw członkowskich. Nadrzędny cel Strategii Lizbońskiej (SL) nie został osiągnięty, strategia Europa 2020 jest jeszcze w trakcie realizacji, a podejmowane w jej ramach programy, inicjatywy i strategie na szczeblach wspólnotowym i krajowym mają pozytywny wpływ na bieżący poziom innowacyjności UE, stwarzając korzystne perspektywy na przyszłość. Innowacyjność staje się warunkiem powodzenia firmy chcącej odnosić sukcesy bez względu na jej wielkość, formę prawną czy termin rozpoczęcia działalności.

Celem artykułu jest określenie poziomu innowacyjności polskich przedsiębiorstw działających na rynku suplementów diety w Polsce w kontekście założeń strategii Europa 2020. Analiza aktywności innowacyjnej przedsiębiorstw została przeprowadzona $\mathrm{w}$ oparciu o metodologię Oslo, na podstawie wskaźników bez-

pośrednich, uwzględniających rezultaty innowacji produktowych, procesowych, organizacyjnych i marketingowych (OECD, 2019) oraz na podstawie autorskiego miernika zagregowanego Sonda innowacyjności. Uwzględniono również mierniki pośrednie aktywności innowacyjnej, m.in.: prowadzenie prac badawczo-rozwojowych, podjęcie współpracy $\mathrm{z}$ nauką, realizację projektów unijnych. Analizę wykonano na podstawie danych, pozyskanych w wyniku badań ankietowych przeprowadzonych wśród 26 przedsiębiorstw z polskim kapitałem, operujących w segmencie suplementów diety. Badania empiryczne uzupełniono, monitorując źródła internetowe techniką clippingu (Kaczmarska, 2017).

Artykuł składa się z sześciu części. Pierwsza odnosi się do założeń proinnowacyjnej polityki Unii Europejskiej, druga - do kryteriów pomiaru i oceny poziomu innowacyjności przedsiębiorstw. Część trzecia prezentuje rynek suplementów diety, czwarta - uwzględnia metodykę badań. 
W części piątej przedstawiono próbę badawczą. Ocena poziomu innowacyjności polskich przedsiębiorstw na rynku suplementów diety przedstawiona została w części szóstej.

\section{Proinnowacyjne strategie Unii Europejskiej}

nnowacyjność stanowi jedno z kluczowych zagadnień strategii gospodarczej Unii Europejskiej. Udokumentowane działania na rzecz współcześnie pojmowanej polityki innowacyjnej krajów członkowskich UE sięgają lat dziewięćdziesiątych XX wieku. Istotny krok w tym kierunku został zapoczątkowany w 1995 r. w „Zielonej Księdze Innowacji” („Green Paper on Innovation”), która stanowiła podstawę do tworzenia europejskiej polityki innowacyjnej w kolejnych latach. W 1996 r. wprowadzony został „Pierwszy plan działań na rzecz innowacyjności w Europie” („The First Action Plan for Innovation in Europe"), który wskazywał trzy obszary aktywności zarówno na szczeblu lokalnym, regionalnym, jak i krajowym: sprzyjanie kulturze innowacji, ustalanie przewodniej struktury dla innowacji (wprowadzenie regulacji prawnych i finansowych) oraz dostosowywanie badań do innowacji (Gust-Bardon, 2011, s. 217-228). W latach 2000-2010 proinnowacyjna polityka Unii Europejskiej realizowana była w ramach Strategii Lizbońskiej, której cel stanowiło osiągnięcie wzrostu konkurencyjności gospodarek europejskich poprzez wdrażanie reform gospodarczych, społecznych i ekologicznych, a w efekcie zniwelowanie luki rozwojowej pomiędzy Stanami Zjednoczonymi i Japonią a krajami członkowskimi Unii Europejskiej (Urząd Komitetu Integracji Europejskiej, 2002). Pomimo udoskonaleń wprowadzanych w trakcie trwania strategii okazała się ona nieskuteczna. Niski poziom wydatków w krajach Unii Europejskiej na badania i rozwój, stanowiący obecnie około $2,12 \%$ PKB, uznawany jest za największą porażkę w realizacji celów ilościowych SL. Zakładany poziom wskaźnika ilościowego stanowił 3\% PKB do roku 2010 (rys. 1).

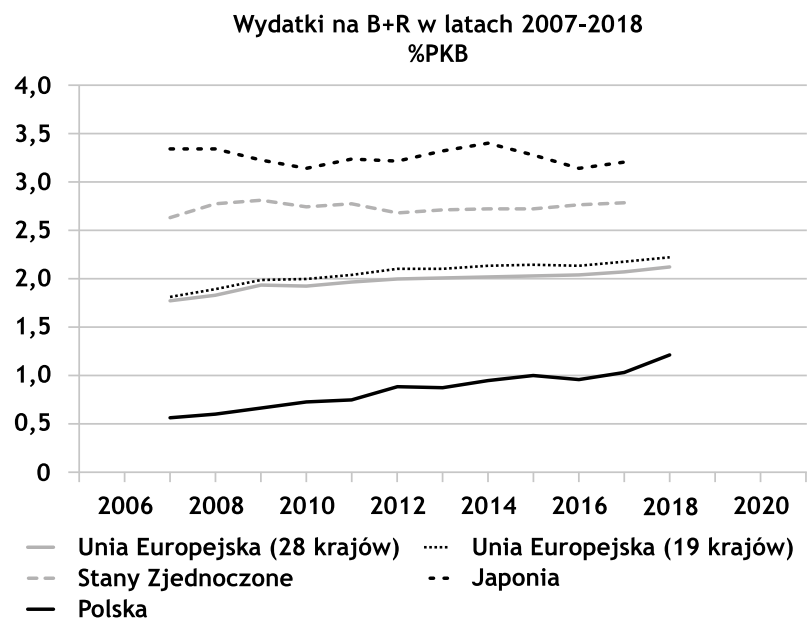

Rys. 1. Wydatki na badania i rozwój w latach 2007-2018 w Unii Europejskiej, Stanach Zjednoczonych i Japonii, \% PKB Źródto: opracowanie wtasne na podstawie: EUROSTAT, 2020
W Polsce w roku 2018 poziom wydatków na badania i rozwój stanowił jedynie 1,21\% PKB. W literaturze przedmiotu jako przyczynę niepowodzenia Strategii Lizbońskiej podaje się m. in. brak ustalonych priorytetów działania, słabe przywództwo polityczne w UE, oportunizm państw członkowskich w stosunku do ograniczenia biurokracji oraz przywilejów socjalnych (Stankiewicz, 2012, s. 285). Przedstawiane są jednak pozytywne aspekty strategii, podkreślające fakt, iż sama próba osiągnięcia ambitnie postawionych celów wskazała Europejczykom nowy sposób myślenia o czynnikach rozwoju (Gust-Bardon, 2011, s. 219).

Planowane inwestycje w badania i rozwój na poziomie 3\% PKB wraz z innymi postulatami Strategii Lizbońskiej znajdują wyraz w, będącej jeszcze w trakcie realizacji, strategii Europa 2020, która obejmuje trzy wzajemnie ze sobą powiązane priorytety (Komunikat Komisji Europa 2020, 2010):

- rozwój inteligentny: rozwój gospodarki opartej na wiedzy i innowacji,

- rozwój zrównoważony: wspieranie gospodarki efektywniej korzystającej z zasobów, bardziej przyjaznej środowisku i bardziej konkurencyjnej,

- rozwój sprzyjający włączeniu społecznemu: wspieranie gospodarki o wysokim poziomie zatrudnienia, zapewniającej spójność społeczną i terytorialną.

Permanentny, kilkudziesięcioletni wpływ polityki Unii Europejskiej na państwa członkowskie istotnie implikuje ich krajowe i regionalne strategie, zwiększające rolę wiedzy i innowacji, jako sił napędowych przyszłego rozwoju. Działania te z kolei znajdują wyraz w proinnowacyjnej aktywności przedsiębiorstw. Innowacyjność staje się główną siłą każdej organizacji, wpisaną na trwałe w jej system zarządzania i kulturę, stanowiąc jeden $\mathrm{z}$ zasadniczych atrybutów, warunkujących uzyskanie przewagi konkurencyjnej na dzisiejszym turbulentnym rynku.

\section{Kryteria pomiaru i oceny innowacyjności przedsiębiorstw}

0 slo Manual definiuje innowację jako wdrożenie nowego lub znacząco udoskonalonego produktu albo procesu, nowej metody marketingowej bądź nowej metody organizacyjnej w praktyce gospodarczej, organizacji miejsca pracy lub w zakresie stosunków z otoczeniem ${ }^{1}$. Formula ta odzwierciedla pogląd austriackiego ekonomisty Josepha Schumpetera, który na początku $\mathrm{XX}$ w., jako pierwszy, wprowadził do nauk ekonomicznych pojęcie innowacyjności. Wytyczne zapisane w Oslo Manual znajdują wyraz w definiowaniu innowacyjności przez Główny Urząd Statystyczny (Malara i in., 2015, s. 9-22). Zgodnie z tą definicją, działalność innowacyjna to szereg działań o charakterze naukowym (badawczym), organizacyjnym, technicznym, handlowym i finansowym, których celem jest zaprojektowanie i wdrożenie nowych lub istotnie ulepszonych produktów czy też procesów. Działalność innowacyjną może prowadzić samo przedsiębiorstwo na swoim terenie lub może polegać 
ona na nabyciu dóbr, usług, a także wiedzy ze źródeł zewnętrznych (Piekut, 2011, s. 87-88). Nowy lub istotnie ulepszony produkt zostaje wdrożony, gdy jest wprowadzony na rynek. Nowe procesy, metody organizacyjne lub metody marketingowe zostają wdrożone, kiedy rozpoczyna się ich faktyczne wykorzystywanie w działalności przedsiębiorstwa. Produkty, procesy oraz metody organizacyjne i marketingowe nie muszą być nowością dla rynku, na którym działa przedsiębiorstwo, ale muszą być nowością przynajmniej dla samego przedsiębiorstwa (GUS, 2014, s. 17).

Działalność innowacyjna polega na angażowaniu się przedsiębiorstw w różnego rodzaju działania naukowe, techniczne, organizacyjne, finansowe i komercyjne, które prowadzą lub mają $\mathrm{w}$ zamierzeniu prowadzić do wdrażania innowacji. Niektóre $\mathrm{z}$ tych działań mają charakter innowacyjny, natomiast inne nie są nowością, lecz są konieczne do wdrażania innowacji. Działalność innowacyjna obejmuje także działalność badawczo-rozwojową $(\mathrm{B}+\mathrm{R})$, która nie jest bezpośrednio związana $\mathrm{z}$ tworzeniem konkretnej innowacji. Działalność innowacyjna przedsiębiorstwa może być (GUS, 2014, s. 17): pomyślnie zakończona wdrożeniem innowacji, bieżąca $\mathrm{w}$ trakcie realizacji lub zaniechana przed wdrożeniem innowacji.

Kryteria pomiaru i oceny innowacyjności przedsiębiorstw zawarte są w podręczniku Oslo Manual (OECD, 2018). Metodologia Oslo oparta jest na modelu powiązań łańcuchowych Rosenberga i Klina z 1986 r. Pierwsze wydanie Podręcznika Oslo miało miejsce w 1992 roku. W metodologii Oslo obowiązuje podejście podmiotowe, koncentrujące się na aktywności innowacyjnej podmiotów, a nie na samych innowacjach. Innowacje są następstwem interakcji i sprzężeń zwrotnych w tworzeniu wiedzy (Nowak, 2012, s. 157). Zgodnie z metodologią Oslo, przedsiębiorstwo aktywne innowacyjnie to takie, które w badanym okresie (najczęściej trzyletnim) wprowadziło przynajmniej jedną innowację produktową, procesową, marketingową, organizacyjną lub realizowało w tym okresie przynajmniej jeden projekt innowacyjny, który został przerwany bądź zaniechany $\mathrm{w}$ trakcie badanego okresu lub nie został do końca tego okresu ukończony (GUS, 2014, s. 31). Oslo Manual definiuje cztery typy innowacji, które $\mathrm{z}$ uwagi na częste ich wykorzystanie $\mathrm{w}$ regulacjach ustawowych, związanych $\mathrm{z}$ oceną projektów oraz programów innowacyjnych, są najczęściej przywoływane (OECD, 2005 cyt. za Knosala i in., 2014, s. 22-23):

1) Innowacja produktowa to wprowadzenie wyrobu lub usługi, które są nowe lub znacząco udoskonalone pod względem swoich cech lub zastosowań. Są to ulepszenia zarówno w obszarach specyfikacji technicznych, jak i komponentów, materiałów, oprogramowania, łatwości obsługi czy innych cech funkcjonalnych.

2) Innowacja procesowa polega na wdrożeniu nowej lub znacząco udoskonalonej metody produkcji lub dostawy. Innowacje procesowe obejmują także nowe lub istotnie ulepszone techniki, urządzenia i oprogramowanie w działalności pomocniczej, takiej jak zaopatrzenie, księgowość, obsługa informatyczna i prace konserwacyjne.

3) Innowacja marketingowa to wdrożenie nowej koncepcji lub strategii marketingowej wiążącej się ze znacznymi zmianami w konstrukcji produktu lub w opakowaniu, dystrybucji, promocji bądź strategii cenowej. Celem innowacji marketingowych jest lepsze zaspokojenie potrzeb klientów, otwarcie nowych rynków zbytu lub nowe pozycjonowanie produktu przedsiębiorstwa na rynku w celu zwiększenia sprzedaży.

4) Innowacja organizacyjna związana jest $z$ wdrożeniem nowej metody organizacyjnej $\mathrm{w}$ przyjętych przez firmę zasadach działania, w organizacji miejsca pracy lub w stosunkach $\mathrm{z}$ otoczeniem, która nie była dotychczas stosowana $\mathrm{w}$ danym przedsiębiorstwie. Innowacje organizacyjne muszą być wynikiem strategicznych decyzji podjętych przez kierownictwo. Nie zalicza się do nich fuzji i przejęć, nawet jeżeli dokonano ich po raz pierwszy.

Analiza literatury przedmiotu wskazuje na brak syntetycznego narzędzia służącego do pomiaru poziomu innowacyjności przedsiębiorstw. Istnieje wiele podejść do procesu oceny innowacyjności, niejednokrotnie wzajemnie wykluczających się, przedstawianych zarówno przez instytucje (GUS, Eurostat), jak również przez indywidualnych badaczy.

Według A. Jasińskiego (1992, s. 25) przedsiębiorstwem innowacyjnym jest podmiot, który prowadzi w szerokim zakresie prace badawczo-rozwojowe (lub dokonuje zakupu nowych produktów czy technologii), przeznacza na tę działalność stosunkowo duże nakłady, systematycznie wdraża nowe rozwiązania naukowo-techniczne, reprezentuje duży udział nowości (wyrobów i technologii) w wolumenie produkcji i usług, stale wprowadza innowacje na rynek. I. Bielski (2000, s. 156) proponuje inne miary innowacyjności przedsiębiorstw: liczbę wprowadzanych innowacji, rodzaje innowacji, innowacje zamierzone, długość cykli prac badawczych i wdrożeniowych, liczbę zgłoszeń patentowych, wysokość wydatków na zakupy B+R, wartość sprzedaży nowych wyrobów na jednego zatrudnionego. A. Pomykalski (2001, s. 15-16) przy analizie innowacyjności bierze pod uwagę następujące kryteria i wskaźniki: liczbę patentów zgłoszonych przez daną firmę, liczbę nowych produktów, badania zadowolenia konsumentów, wzrost przychodów lub udziału w rynku. S. Motyka (2011, s. 160-168) proponuje nowe podejście do oceny poziomu innowacyjności przedsiębiorstwa: Strategiczną Kartę Wyników (SKW) oraz Metodę Analitycznego Procesu Hierarchicznego (AHP). Metodologię oceny i klasyfikacji polskich przedsiębiorstw z punktu widzenia ich innowacyjności opracował również Instytut Nauk Ekonomicznych PAN, opierając się na wskazówkach zawartych w Podręczniku Oslo (Szwajca, 2011, s. 61-76). W Polsce kompleksowe badania innowacji od 2000 r. przeprowadza GUS², którego system badań statystycznych opiera się na międzynarodowych zaleceniach metodologicznych prezentowanych w kolejnych wydaniach Podręcznika Oslo Manual. 


\section{Charakterystyka rynku suplementów diety}

$\mathbf{R}$ ynek suplementów diety jest najszybciej rozwijającym się segmentem sektora farmaceutycznego. Według firmy badawczej PMR (2019), w 2018 roku wartość rynku suplementów diety w Polsce wyniosła 5,4 mld zł. Do 2023 roku prognozowany jest średnioroczny wzrost wartości rynku na poziomie 3-5\%. Zgodnie z badaniami przeprowadzonymi przez agencję Badań Rynku i Opinii SW Research (2007), suplementy diety stosuje aż $72 \%$ dorosłych Polaków, przy czym zaledwie $17 \%$ z nich konsultuje tę kwestię z lekarzem lub farmaceutą. Przedsiębiorstwa działające na rynku suplementów diety charakteryzują się wysoką aktywnością w zakresie wprowadzania na rynek nowych produktów i procesów. W obecnym stanie prawnym każdy podmiot może wprowadzić na rynek suplement diety, deklarując jedynie jego skład organom sanitarnym w drodze tzw. notyfikacji ${ }^{3}$. W rejestrze Głównego Inspektoratu Sanitarnego (GIS) w roku 2009 dokonano 3066 notyfikacji, a dziesięć lat później, w roku 2019 - aż 15 170. W rejestrze GIS (2020) w latach 2007-2019 wpisano łącznie ponad 84 tys. produktów zgłoszonych jako suplementy diety. W świetle obowiązującego prawa suplement diety nie jest produktem leczniczym. Zgodnie z ustawą o bezpieczeństwie żywności i żywienia z dnia 25 sierpnia 2006 r., suplement diety jest środkiem spożywczym, którego celem jest uzupełnienie normalnej diety. Wprowadzany jest do obrotu w postaci kapsułek, tabletek, drażetek, saszetek (Dz.U. z 2015 r., poz. 594, 1893). Suplementy diety są produktami stanowiącymi źródło skoncentrowanych składników odżywczych i innych składników o działaniu fizjologicznym (Jarosz, 2008, s. 11-12).

Segment suplementów diety poza szybkim tempem wzrostu zapewnia przedsiębiorcom również szybki zwrot $\mathrm{z}$ inwestycji poniesionych na wdrażanie nowych produktów z uwagi na łatwość i szybkość wprowadzenia tych preparatów do obrotu. Dodatkowo ten segment rynku farmaceutycznego w znacznie mniejszym stopniu podlega ingerencji państwa $\mathrm{w}$ mechanizm jego działania, niż ma to miejsce $\mathrm{w}$ przypadku leków nabywanych na receptę i leków OTC ${ }^{4}$. Uwarunkowania te sprawiają, iż rynek suplementów diety jest atrakcyjny dla nowych podmiotów, które niejednokrotnie w krótkim okresie czasu potrafią skutecznie konkurować z dużymi korporacjami farmaceutycznymi, nie tylko o produkty, ale również o ich pozycjonowanie $\mathrm{w}$ świadomości nabywców. Zwiększająca się konkurencja pomiędzy producentami farmaceutyków skłania ich do podejmowania coraz skuteczniejszych aktywności proinnowacyjnych. Z uwagi na powyższe aspekty zasadne jest dokonanie oceny poziomu innowacyjności polskich przedsiębiorstw działających na rynku suplementów diety w Polsce.

Badania w zakresie działalności innowacyjnej przedsiębiorstw farmaceutycznych w Polsce prowadzi GUS. Według informacji sygnalnych z dn. 28.10.2019 r. co druga firma $\mathrm{z}$ tego sektora (52\%) dostarczyła na rynek innowacyjne produkty (GUS, 2019). Cykliczny monitoring innowacyjności polskich przedsiębiorstw przeprowadzany jest również przez Polską Agencję Rozwoju Przedsiębiorczości (PARP, 2019). W literaturze przedmiotu brak jest jednak opracowań dotyczących segmentu suplementów diety.

\section{Metoda badawcza}

$\mathbf{N}$ a podstawie analizy literatury przedmiotu oraz biorąc pod uwage powszechność stosowania wskaźników bezpośrednich, a także ich wymierny charakter, w niniejszej pracy dokonano pomiaru aktywności innowacyjnej przedsiębiorstw $\mathrm{z}$ zastosowaniem metodologii Oslo. Przyjęto, iż przedsiębiorstwo aktywne innowacyjnie to takie, które w okresie trzyletnim (w latach 2016-2018) wprowadziło przynajmniej jedną innowację produktową, procesową, marketingową lub organizacyjną. Do oceny działalności innowacyjnej podmiotów zastosowano wskaźnik udziału przedsiębiorstw innowacyjnych w ogólnej zbiorowości. Analizę przeprowadzono na podstawie innowacji pomyślnie zakończonych wdrożeniem. Pominięto innowacje bieżące ( $w$ toku), będące $\mathrm{w}$ trakcie realizacji lub zaniechane przed wdrożeniem innowacji głównie ze względu na konieczność zachowania tajemnicy służbowej przez pracujące nad nimi zespoły zadaniowe. W wielu przedsiębiorstwach nad wdrożeniem nowych suplementów diety pracują wąskie interdyscyplinarne zespoły wdrożeniowe, składające się ze specjalistów $B+R$, marketingu, technologów. Członkowie tych zespołów są zobligowani do nieudostępniania informacji dotyczących postępu prac czy uzyskiwanych wyników, przede wszystkim $z$ uwagi na dużą konkurencyjność w branży farmaceutycznej.

Rynek suplementów diety charakteryzuje wysoka liczba wdrożeń produktowych, związana głównie $\mathrm{z}$ brakiem barier wejścia na rynek, m.in. wymogów polegających na obowiązkowym badaniu jakościowym suplementów diety, brakiem opłat za ich rejestrację oraz certyfikację i kwalifikację. Dlatego liczba innowacji produktowych znacznie przewyższa liczbę wdrożonych innowacji procesowych, organizacyjnych czy marketingowych. $Z$ tego względu do pomiaru poziomu innowacyjności badanych podmiotów zaproponowano również analizę wielokryterialną. $\mathrm{Na}$ jej podstawie dla każdego badanego przedsiębiorstwa obliczono autorski miernik zagregowany, który nazwano Sondq innowacyjności. Wyszczególniono cztery czynniki: liczbę innowacji produktowych w latach 2016-2018 oraz trzy czynniki zerojedynkowe określające, czy wdrożono innowacje procesowe, organizacyjne i marketingowe w latach 2016-2018 (przypisano wartość 0, jeśli nie została wdrożona taka innowacja, lub 1, jeśli została wdrożona). W oparciu o zwiad badawczy przeprowadzony z jedenastoma praktykami rynku farmaceutycznego w Polsce, dla poszczególnych czynników dobrano wagi określające istotność każdego $\mathrm{z}$ nich ${ }^{5}$. Najniższą wagę przyjęto dla innowacji produktowych $(0,1)$, ponieważ są domeną rynku suplementów diety i wynikają z jego uwarunkowań, natomiast dla każdego z pozostałych czynników (innowacji procesowych, organizacyjnych i marketingowych) ustalono wagę po 0,3 . W celu zagregowania różnorodnych czynników w jeden miernik, czynnik liczbę innowacji 
produktowych poddano normalizacji zgodnie ze wzorem (standardowa normalizacja):

$$
k_{\text {norm }}=\frac{k-\min }{\max -\min }
$$

$k_{\text {norm }}$ - wartość kryterium znormalizowanego (zawiera się w przedziale $[0,1])$,

$k$ - wartość kryterium przed normalizacją,

max - maksymalna wartość kryterium,

min - minimalna wartość kryterium.

Wartość zagregowanego miernika Sonda innowacyjności stanowi sumę iloczynów czynników oraz poszczególnych wag określających istotność danego czynnika:

$$
w_{s}=\sum_{i} w_{i} \cdot k_{i}
$$

$w_{s}$ - wartość miernika Sonda innowacyjności,

$w_{i}$ - wartość i-tej wagi,

$\boldsymbol{k}_{i}$ - wartość i-tego czynnika.

Do oceny aktywności innowacyjnej badanych podmiotów zastosowano również mierniki pośrednie, m.in.: prowadzenie prac badawczo-rozwojowych, podjęcie współpracy z nauką, realizację projektów unijnych. Celowo pominięto jeden $\mathrm{z}$ parametrów proponowanych często przez badaczy: ilość nagród przyznanych dla marek lub produktów. W przypadku rynku suplementów diety nie jest to miernik obiektywny, gdyż w praktyce o przyznanie nagrody ubiega się sam przedsiębiorca, dokonując wysokich opłat rejestracyjnych i weryfikacyjnych. Laureaci mogą umieszczać informację o wyróżnieniu produktu nagrodą (m.in. Złoty Otis, Nagroda Profesorów Farmacji) zazwyczaj po podpisaniu umowy licencyjnej i uiszczeniu wynikających z niej opłat. Pozyskanie nagród przez przedsiębiorstwa oceniać należy w zakresie aktywności marketingowej firm, gdyż stanowią one jedną $\mathrm{z}$, coraz już mniej skutecznych, form promocji preparatów.

Badania empiryczne wykonano $\mathrm{z}$ zastosowaniem techniki ankietowania w okresie październik 2019 r. - grudzień 2019 r., dokonując celowego doboru próby. Zbiorowość statystyczną stanowiło 80 polskich przedsiębiorstw operujących w segmencie suplementów diety: wyłącznych wytwórców środków spożywczych, a także podmiotów łączących w swojej ofercie produkcję suplementów z lekami OTC, Rx, wyrobami medycznymi i kosmetykami. Kontakt $\mathrm{z}$ badanymi podmiotami odbywał się trzykrotnie: jednorazowo telefonicznie oraz dwukrotnie pocztą e-mail. Uzyskano wskaźnik odpowiedzi na poziomie $33 \%$. Aż 24\% firm zdecydowanie odmówiło wzięcia udziału w badaniu, powołując się głównie na politykę firmy. Kwestionariusz ankietowy skierowano do pracowników, którzy w badanych firmach pełnili funkcje menedżerskie średniego lub wyższego szczebla. Bazę danych przedsiębiorstw pozyskano z internetowej Krajowej Bazy Produktów Ochrony Zdrowia (KBPOZ), obejmującej produkty branżowe $\mathrm{z}$ rynku farmaceutycznego i szpitalnego (http://kbpoz.gs1.pl/, 2020). Badania przeprowadzono techniką CAWI (ang. Computer-Assisted Web Interview) - wywiadów internetowych, w których pytania ankietowe przekazywane są za pośrednictwem
Internetu. Pytania zawarte $\mathrm{w}$ ankiecie dotyczyły następujących aktywności proinnowacyjnych:

- wprowadzenie innowacji produktowej, procesowej, organizacyjnej, marketingowej w ciągu ostatnich 3 lat,

- prowadzenie działalności badawczo-rozwojowej we własnych centrach / ośrodkach / działach / komórkach,

- outsourcing w zakresie B+R,

- współpraca z nauką,

- realizacja projektów unijnych,

- otrzymane nagrody/wyróżnienia wyłącznie w zakresie innowacyjności.

Zastosowanie numeru token w badaniach CAWI umożliwiło powiązanie otrzymanych odpowiedzi z respondentem. $\mathrm{Na}$ tej podstawie oraz w oparciu o Rejestr produktów Departamentu Żywności Prozdrowotnej Głównego Inspektoratu Sanitarnego przeanalizowano liczbę wdrożeń produktowych (notyfikowanych suplementów diety) w każdym z minionych trzech lat: 2016 r., 2017 r. oraz 2018 r. W badaniach empirycznych zastosowano również monitoring mediów (clipping) jako technikę uzupełniającą, polegającą na analizie wszelkich informacji, komunikatów, jakie pojawiają się w mediach na temat danej organizacji (http://www.newsline.pl/naukapublicrelations/slownikpojec/art14.html, 2020). Clipping (press clipping) jest metodą pomiaru efektywności działań public relations (PR). Obecnie ta technika zbierania informacji znalazła szersze zastosowanie niż tylko w PR (Kaczmarska, 2017). Monitorowano treści witryn internetowych badanych przedsiębiorstw i stron internetowych związanych pośrednio z badanymi podmiotami (strony Krajowej Rady Suplementów i Odżywek, Związku Pracodawców Innowacyjnych Firm Farmaceutycznych, Polskiego Związku Producentów Leków Bez Recepty) oraz treści branżowych materiałów prasowych. Analiza informacji ukierunkowana była na zagadnienia innowacyjności, w szczególności dotyczyła rodzaju wdrażanych innowacji marketingowych, produktowych, procesowych, organizacyjnych oraz form nagród otrzymanych przez firmy za działalność innowacyjną.

\section{Próba badawcza}

7 godę na udział w badaniu ankietowym wyraziło 26 - przedsiębiorstw, będących spółkami prawa handlowego z dominującym polskim kapitałem, działających na rynku suplementów diety na terenie całej Polski. Liczebność próby badawczej ograniczyła możliwości przeprowadzenia badań statystycznych stwierdzających istotność statystyczną uzyskanych wyników, jednakże segment rynku, w którym przeprowadzono badania, reprezentowany jest przez niewielką liczbę podmiotów. Próba badawcza stanowiła 32,5\% zbiorowości statystycznej. Aż 69\% badanych podmiotów stanowiły spół ki z ograniczoną odpowiedzialnością, 15\% - spółki cywilne oraz po $8 \%$ spółki akcyjne i spółki komandytowe. Wszystkie badane przedsiębiorstwa produkowały suplementy diety, $23 \% \mathrm{z}$ nich zajmowało się również produkcją leków $\mathrm{Rx}^{6}, 42 \%$ - leków OTC i po $46 \%$ - produkcją kosmetyków i wyrobów medycznych. Biorąc pod uwagę liczbę zatrudnionych osób, $19 \%$ badanych podmiotów to przedsiębiorstwa duże, liczące powyżej 249 osób (w tym jedna firma - powyżej 499 osób), $27 \%$ to firmy średnie posiadające do 249 pracowników, 31\% 
to przedsiębiorcy mali o liczbie pracowników nieprzekraczającej 49 osób oraz 23\% to mikroprzedsiębiorstwa zatrudniające do 9 osób. Znaczny odsetek próby badawczej, bo aż 38\%, stanowiły podmioty prowadzące działalność na polskim rynku od ponad 15 lat, 50\% funkcjonowało od 6 do 15 lat, a $12 \%$ - od 2 do 5 lat.

Największy odsetek wśród respondentów stanowili prezesi / dyrektorzy zarządzający (27\%). Kwestionariusz ankietowy został również wypełniony przez dyrektorów / kierowników marketingu (19\% respondentów), dyrektorów / kierowników sprzedaży (12\%), innych dyrektorów / kierowników (12\%), kierowników ds. kluczowych klientów (8\%), specjalistów ds. marketingu (8\%). Pozostały odsetek badanych osób tworzyli pracownicy pełniący inne funkcje, np. menedżer produktu, specjalista działu B+R.

\section{Wyniki badań}

yniki przeprowadzonych badań wskazują, że wszystkie badane polskie przedsiębiorstwa, działające na rynku suplementów diety w Polsce wykazały w latach 2016-2018 aktywność innowacyjną, wdrażając co najmniej jedną $\mathrm{z}$ innowacji: produktową, procesową, organizacyjną, marketingową. Zatem dla badanej grupy podmiotów przyjęty do oceny wskaźnik udziału przedsiębiorstw innowacyjnych w ogólnej zbiorowości wynosi 100\%. Aż 85\% przedsiębiorstw wprowadziło w analizowanym okresie innowację produktową, 77\% - innowację marketingową, 69\% - innowację procesową, $54 \%$ - innowację organizacyjną (rys. 2).

\section{Innowacje produktowe}

W okresie od 2016 do 2019 roku badane przedsiębiorstwa dokonały zgłoszenia do rejestru produktów Departamentu Żywności Prozdrowotnej Głównego Inspektoratu Sanitar- nego, wprowadzając tym samym do obrotu 666 suplementów diety. Liczbę preparatów wdrożonych przez badane przedsiębiorstwa na rynek kolejno w latach 2016-2019 przedstawia rysunek 3 .

Najwięcej zgłoszeń dokonały firmy Olimp Laboratories Sp. z o.o. (33\% ogólnej liczby zgłoszeń), Activepharm Labs Sp. z o.o. Sp. K. (15\%), Global Pharma CM Sp. z o.o. (14\%), Oleofarm Sp. z o.o. (11\%). Liczbę wdrożonych preparatów w latach 2016-2019 dla wybranych przedsiębiorstw przedstawia rysunek 4 .

Przedmiotem badań był również rozkład innowacji produktowych w latach 2016-2018 w zależności od wielkości firmy, liczby lat funkcjonowania na rynku i formy prawnej (tab. 1). W latach 2016-2018 najwyższy odsetek innowacji produktowych przypada na duże firmy, zatrudniające powyżej 250 osób, stanowiące $19 \%$ badanych podmiotów i wynosi on odpowiednio w kolejnych latach: 47\%, 49\%, 58\%. Podobnie, uwzględniając formę prawną przedsiębiorstw, najwięcej wdrożeń produktowych dokonały spółki $\mathrm{z}$ ograniczoną odpowiedzialnością, mające największy udział w badanej próbie (69\%) - od $62 \%$ do $78 \%$ wdrożeń rocznie. Biorąc pod uwagę liczbę lat funkcjonowania na rynku, niski odsetek (7\%-15\% rocznie) wprowadzanych do obrotu suplementów diety przypada na podmioty funkcjonujące na rynku 2-5 lat, które stanowią jedynie $12 \%$ badanych przedsiębiorstw. Najliczniejsza grupa przedsiębiorstw $\mathrm{z}$ ponad 15-letnim stażem rynkowym wdrożyła w badanym okresie od 39\% do 52\% produktów rocznie.

\section{Innowacje marketingowe, procesowe, organizacyjne}

Innowacje marketingowe zostały wprowadzone przez wszystkie spośród dużych firm, zatrudniające powyżej 249 osób oraz przez $86 \%$ spośród firm średnich, liczących od 50 do 249 pracowników. Uwzględniając formę prawną,

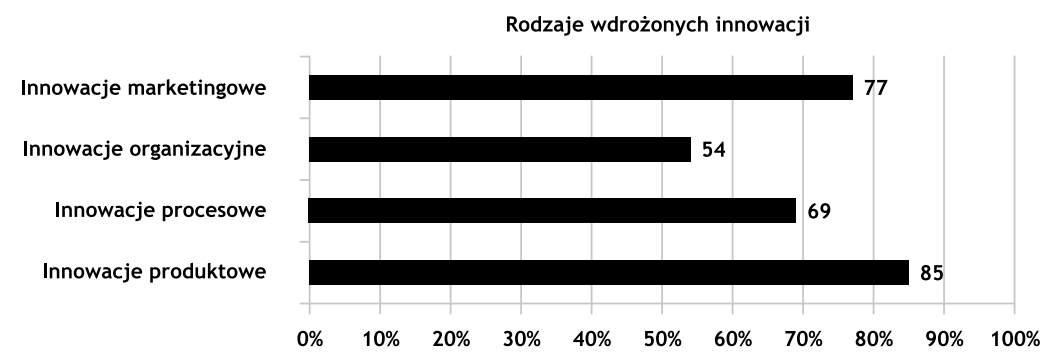

Rys. 2. Rodzaje wdrożonych innowacji w latach 2016-2018 przez polskie przedsiębiorstwa działające na rynku suplementów diety Źródło: opracowanie własne

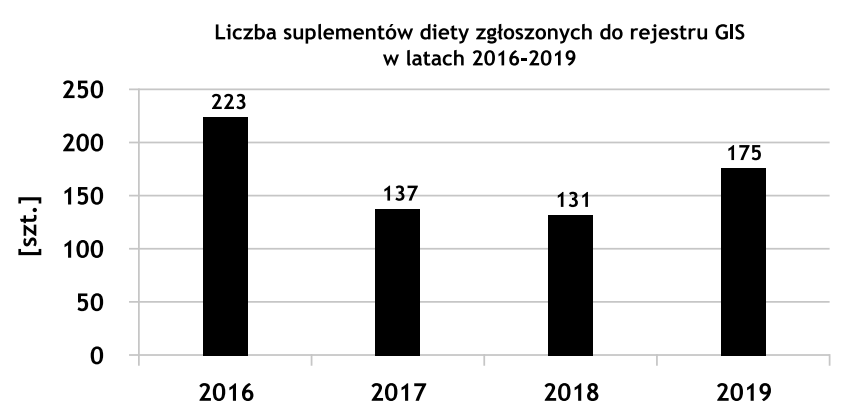

Rys. 3. Liczba suplementów diety zgłoszonych przez badane podmioty do rejestru GIS w latach 2016-2019

Źródło: opracowanie wtasne 
Liczba suplementów diety zgłoszonych do rejestru GIS w latach 2016-2019 przez wybrane podmioty

GLOBAL PHARMA CM SP. Z 0.0 .

OLIMP LABORATORIES SP. Z O.O.

ACTIVEPHARM LABS SP. Z O.O. SP.K.

OLEOFARM SP. Z O.o.

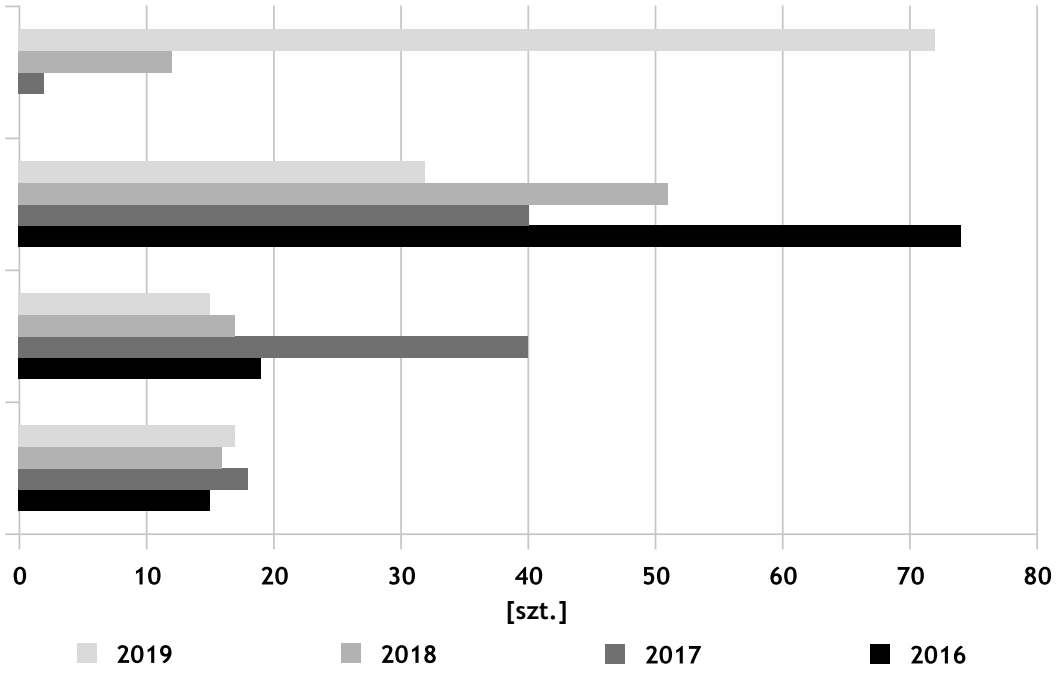

Rys. 4. Liczba suplementów diety zgtoszonych przez wybrane podmioty do rejestru GIS w latach 2016-2019 Źródto: opracowanie własne

Tabela 1. Liczba i odsetek innowacji produktowych w latach 2016-2018 w zależności od wielkości firmy, liczby lat funkcjonowania na rynku i formy prawnej

\begin{tabular}{|c|c|c|c|c|c|c|c|}
\hline & & & & & & & \\
\hline & & \multicolumn{6}{|c|}{ Innowacje produktowe } \\
\hline & & \multicolumn{2}{|c|}{$2016 \mathrm{r}$. } & \multicolumn{2}{|c|}{2017 r. } & \multicolumn{2}{|c|}{$2018 \mathrm{r}$. } \\
\hline & & Liczba & $\%$ & Liczba & $\%$ & Liczba & $\%$ \\
\hline \multirow{4}{*}{ } & $<10$ osób & 10 & 4 & 3 & 2 & 2 & 2 \\
\hline & 10 - 49 osób & 60 & 27 & 52 & 38 & 34 & 26 \\
\hline & $50-249$ osób & 49 & 22 & 15 & 11 & 19 & 15 \\
\hline & pow. 250 osób & 104 & 47 & 67 & 49 & 76 & 58 \\
\hline \multirow{4}{*}{ 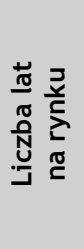 } & $2-5$ lat & 34 & 15 & 9 & 7 & 19 & 15 \\
\hline & $6-10$ lat & 57 & 26 & 54 & 39 & 21 & 16 \\
\hline & $11-15$ lat & 22 & 10 & 21 & 15 & 23 & 18 \\
\hline & pow.15 lat & 110 & 49 & 53 & 39 & 68 & 52 \\
\hline \multirow{4}{*}{ 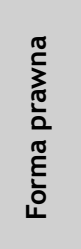 } & Spółka z o.o. & 154 & 69 & 85 & 62 & 102 & 78 \\
\hline & Spółka akcyjna & 11 & 5 & 2 & 1 & 3 & 2 \\
\hline & Spółka cywilna & 39 & 17 & 10 & 7 & 9 & 7 \\
\hline & Spółka komandytowa & 19 & 9 & 40 & 29 & 17 & 13 \\
\hline
\end{tabular}

Źródto: opracowanie wtasne

wielkość i staż rynkowy przedsiębiorstwa, spośród podmiotów aktywnych w obszarze innowacji marketingowych, 70\% stanowiły spółki z ograniczoną odpowiedzialnością, 35\% - firmy zatrudniające 10-49 pracowników, $50 \%$ - producenci obecni na rynku ponad 15 lat. Najczęściej wdrażanym rodzajem innowacji marketingowej było wprowadzenie istotnych zmian $\mathrm{w}$ projekcie bądź konstrukcji opakowania, zastosowanie nowych form ekspozycji produktów oraz nowych technik promocji suplementów diety często powiązanych $\mathrm{z}$ działaniami z zakresu społecznej odpowiedzialności biznesu. Badane przedsiębiorstwa dokonywały zmian opakowań preparatów zwłaszcza w zakresie uszlachetnień (hot-stampin$\mathrm{gu}^{7}$, tłoczeń wypukłych i wklęsłych, lakierowania UV 
z efektami hybrydowymi), które są konieczne ze względu na szybką rotację suplementów diety, podobną do produktów FMCG. Rola opakowania suplementów diety jest szczególnie istotna, gdyż ułatwia koncentrację na marce, uwzględnia percepcję konsumenta, umożliwiając efektywną współpracę ze sprzedawcami.

W zakresie innowacji procesowych, do najczęściej wymienianych należą: ulepszenie oprogramowania w działalności pomocniczej oraz projektowanie lub wprowadzenie nowej technologii wytwarzania różnych form suplementów, m.in. zawiesin, roztworów, tabletek powlekanych powłoką dojelitową, kapsułek żelatynowych twardych $\mathrm{z}$ warstwą olejową. Innowacje procesowe zostały wdrożone przez $69 \%$ badanych podmiotów, przy czym uwzględniając formę prawną, wielkość i profil działalności przedsiębiorstwa, najwięcej innowacji wdrożyły spółki $\mathrm{z}$ ograniczoną odpowiedzialnością (72\%), firmy liczące 10-49 pracowników (39\%), podmioty obecne na rynku 6-10 lat (33\%).

Innowacje organizacyjne wprowadziło $54 \%$ badanych przedsiębiorstw. Najczęściej wskazywane są nowe metody organizacyjne $\mathrm{w}$ zakresie stosunków $\mathrm{z}$ otoczeniem (instytucjami publicznymi, innymi przedsiębiorstwami), systemów szkoleniowych, decentralizacji, dezintegracji wydziałów, zakładania fundacji działających w zakresie społecznej odpowiedzialności biznesu oraz współpracy i integracji środowiska naukowego, przemysłu farmaceutycznego, medycznego, biotechnologicznego. Wśród podmiotów aktywnych w obszarze innowacji organizacyjnych $61 \%$ stanowią spółki z ograniczoną odpowiedzialnością, $33 \%$ to małe przedsiębiorstwa, liczące 10-49 pracowników, 22\% - firmy prowadzące działalność 6-10 lat.

\section{Zagergowany miernik Sonda innowacyjności}

Pomiar poziomu innowacyjności badanych podmiotów zaproponowano również na podstawie analizy wielokryterialnej. Uwzględniając cztery czynniki: innowacje produktowe, procesowe, organizacyjne i marketingowe, dla każdego przedsiębiorstwa obliczono miernik zagregowany, nazwany Sondą innowacyjności, którego wartości zawarte są w przedziale [0,1]. Rysunek 5 przedstawia rozkład zagregowanego miernika Sonda innowacyjności.

W oparciu o uzyskane wartości miernika Sonda innowacyjności badane przedsiębiorstwa zaklasyfikowano do grup przedstawionych w tabeli 2 .

Tabela 2. Grupy przedsiębiorstw według wartości miernika Sonda innowacyjności

\begin{tabular}{|c|c|}
\hline $\begin{array}{c}\text { Wartość miernika } \\
\text { Sonda innowacyjności }\end{array}$ & Grupa \\
\hline $0-0,29$ & Słaby innowator \\
\hline $0,30-0,89$ & Umiarkowany innowator \\
\hline $0,9-0,95$ & Silny innowator \\
\hline $0,96-1$ & Lider innowacyjności \\
\hline
\end{tabular}

Źródło: opracowanie własne

Najwięcej, bo aż $46 \%$ badanych podmiotów zakwalifikowało się do grupy silnych innowatorów. Wszystkie te przedsiębiorstwa wdrożyły innowację procesową, marketingową i organizacyjną, a $83 \% \mathrm{z}$ nich wprowadziło na rynek nowe suplementy diety. Grupę umiarkowanych innowatorów stanowi 35\% przedsiębiorstw, które wdrożyły co najmniej jedną z innowacji: procesową, marketingową lub organizacyjną. Nowe suplementy diety zostały wprowadzone na rynek przez $78 \%$ tej grupy, innowacje procesowe wdrożyło $56 \%$ firm, innowacje marketingowe - 78\%, a innowacje organizacyjne - tylko $11 \%$. Najwyższy wskaźnik w tej grupie $(0,6-0,89)$ uzyskały podmioty, które wdrożyły trzy typy innowacji. Wszystkie te firmy wprowadziły innowacje produktowe i procesowe. Do grupy liderów innowacji (4\%) należy jedno przedsiębiorstwo, które w badanym okresie wdrożyło innowacje marketingowe, procesowe i organizacyjne oraz wprowadziło na rynek aż 165 suplementów diety.

Przedsiębiorstwa, które wdrożyły jedynie innowacje produktowe, stanowiły grupę (15\%) słabych innowatorów (rys. 6).

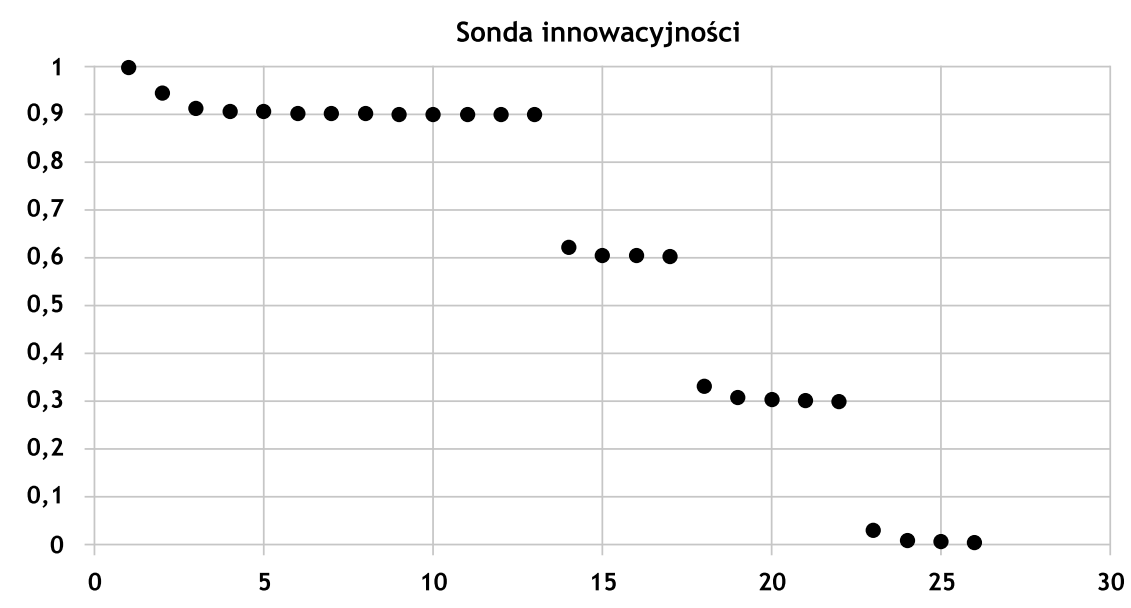

Rys. 5. Rozkład zagregowanego miernika Sonda innowacyjności dla badanych przedsiębiorstw

Źródło: opracowanie własne 


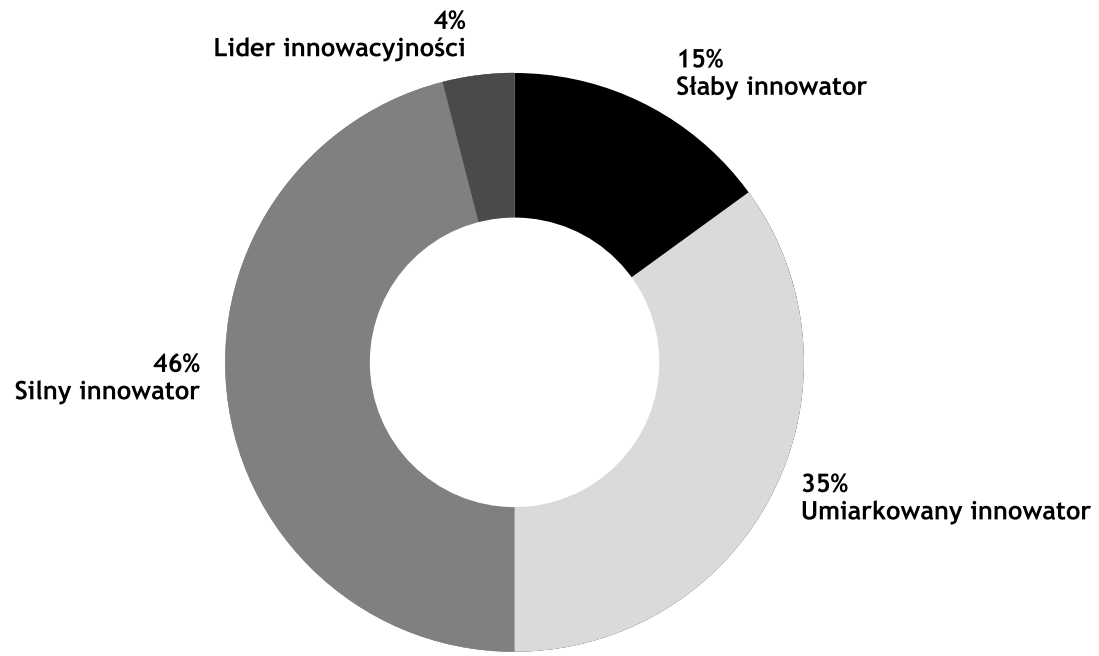

Rys. 6. Grupy innowatorów według miernika Sonda innowacyjności Źródto: opracowanie wtasne

\section{Badania i rozwój, współpraca z nauką, projekty unijne, wyróżnienia i nagrody}

Przedmiotem analizy była również działalność badanych przedsiębiorstw $\mathrm{w}$ sferze badawczo-rozwojowej, mająca pośredni związek z wdrażaniem innowacji. Aż 69\% badanych podmiotów prowadziło działania badawczo-rozwojowe, $38 \% \mathrm{z}$ nich wykonywało tę aktywność we własnych komórkach: zarówno małych laboratoriach chemicznych, biologicznych, działach i pionach $\mathrm{B}+\mathrm{R}$, jak również w dużych, nowoczesnych centrach badawczo-rozwojowych, centrach biotechnologicznych lub wyodrębnionych jednostkach biznesowych dedykowanych wyłącznie sferze B+R. Znaczny odsetek (31\%) podmiotów deklarował również outsourcing badań i rozwoju w wyspecjalizowanych instytutach badawczych oraz zakup licencji i prowadzenie wspólnej działalności badawczej z podmiotami zewnętrznymi.

Kolejną kwestią stanowiącą przedmiot badań była współpraca przedsiębiorstw $\mathrm{z}$ instytucjami naukowymi. Aż $62 \%$ badanych firm podjęło współpracę z jednostkami naukowymi, m.in. Instytutami PAN (Biochemii i Biofizyki), Politechniką Wrocławską, Uniwersytetem Medycznym we Wrocławiu i Poznaniu, Uniwersytetem Jagiellońskim, Uniwersytetem Rzeszowskim, SGGW w Warszawie. Wśród firm współpracujących z nauką znaczny odsetek (56\%) stanowiły firmy prowadzące działalność od ponad 15 lat.

Wyniki badań wskazują, iż połowa badanych przedsiębiorstw uzyskała publiczne wsparcie na działalność innowacyjną w zakresie projektów współfinansowanych przez Unię Europejską. Aż 61\% firm realizujących projekty unijne na rzecz innowacyjności było obecnych na rynku ponad 15 lat, a 31\% to firmy małe, liczące 10-49 osób.

Przedmiotem badań była również kwestia nagród, przyznanych przedsiębiorstwom przez niezależne gremia, za prowadzoną działalność na rzecz innowacji. Wśród badanych podmiotów 35\% firm deklarowało uzyskanie takiego wyróżnienia. Były to m.in.: Nagroda Gospodarcza Prezydenta RP, Nagroda Fair Play za szczególną działalność innowacyjną, Podkarpacka Nagroda Gospodarcza, Złota Statuetka Lidera Polskiego Biznesu, Orzeł Wprost, Polska Nagroda Innowacyjności.

\section{Podsumowanie}

ednym z najbardziej innowacyjnych segmentów polskiej gospodarki jest rynek suplementów diety, reprezentowany zarówno przez producentów leków i wyrobów farmaceutycznych, jak i producentów artykułów spożywczych. $\mathrm{Na}$ podstawie zagregowanego miernika Sonda innowacyjności $46 \%$ badanych podmiotów należy zakwalifikować jako silnych innowatorów, $4 \%$ stanowią liderzy innowacji. Wysoki odsetek (35\%) przypada na umiarkowanych innowatorów. Słabi innowatorzy to grupa $15 \%$ firm. Aż $85 \%$ badanych przedsiębiorstw wdrożyło innowacje produktowe, $77 \%$ - innowacje marketingowe, $69 \%$ - innowacje procesowe i $54 \%$ - innowacje organizacyjne.

Wysoki odsetek (69\%) podmiotów stanowiły firmy prowadzące działalność badawczo-rozwojową zarówno we własnych komórkach, jak i zlecając ją podmiotom zewnętrznym. Współpracę z uczelniami wyższymi i jednostkami naukowo-badawczymi deklarowało $62 \%$ przedsiębiorstw. Niewielki odsetek, bo jedynie 35\% firm uzyskało wyróżnienia i nagrody za prowadzoną działalność na rzecz innowacji.

Brak barier związanych $\mathrm{z}$ wprowadzeniem produktu na rynek, brak opłat rejestracyjnych i oczekiwania na rejestrację przyczyniają się do wysokiej liczby wdrażanych na rynek produktów, a tym samym wysokiej liczby innowacji produktowych. Projektowanie suplementów diety o nietypowych formach podania i/lub innowacyjnym składzie stanowi obszar, w którym możliwa jest szybka reakcja na najnowsze doniesienia medyczne i który jest szczególnie predestynowany do współpracy z nauką, do poszerzania działań w zakresie badań i rozwoju. Wiodące firmy oferujące suplementy diety są obecnie w trakcie realizacji oraz $\mathrm{w}$ ciągu najbliższych dekad planują wdrożenie innowacyjnych technologii wytwarzania preparatów oraz opracowanie innowacyjnego składu produktów. Przedsiębiorstwa te w ciągu minionej dekady uzyskały wsparcie finansowe na realizację innowacyjnych przedsięwzięć ( $50 \%$ badanych podmiotów).

Wysoki poziom innowacji produktowych, charakterystyczny dla przedsiębiorstw oferujących suplementy diety wynika ze specyficznych uwarunkowań tego rynku, jednak intensywność działań $\mathrm{w}$ sferze $\mathrm{B}+\mathrm{R}$, współpraca $\mathrm{z}$ nauką, 
wdrażane innowacje marketingowe, procesowe czy zaangażowanie $w$ realizację projektów dofinansowanych ze środków unijnych, są wyrazem wysokiej orientacji proinnowacyjnej tych podmiotów.

mgr inż. Marta Hrydziuszko

Politechnika Wrocławska

Wydział Informatyki i Zarządzania

ORCID: 0000-0002-8137-3823

e-mail: marta.hrydziuszko@pwr.edu.pl

\section{dr hab. inż. Grzegorz Chodak, prof. uczelni \\ Politechnika Wrocławska \\ Wydział Informatyki i Zarządzania \\ ORCID: 0000-0002-9604-482X \\ e-mail: grzegorz.chodak@pwr.edu.pl}

\section{Przypisy}

1) Oslo Manual - międzynarodowy podręcznik metodologiczny z dziedziny badań statystycznych innowacji, czwarty w porządku chronologicznym, w serii podręczników metodologicznych OECD i Eurostatu.

2) Pierwsze badania innowacji w sektorze usług przeprowadzone zostały w 2000 r. i dotyczyły lat 1997-1999.

3) Zgodnie z Ustawą z dnia 25 sierpnia 2006 r. o bezpieczeństwie żywności i żywienia (Dz.U. 2010.136.914), zamiar wprowadzenia do obrotu suplementu diety jest zgłaszany $\mathrm{w}$ drodze powiadomienia Głównego Inspektora Sanitarnego (GIS), który stanowi instytucję nadzorującą rynek żywności, w tym suplementów diety.

4) Leki OTC (Over The Counter) - leki nabywane bez recepty.

5) Rozmówcy posiadali co najmniej pięcioletnie menedżerskie doświadczenie zawodowe $\mathrm{w}$ obszarze rynku suplementów diety, zdobyte w obrębie jednej lub kilku firm.

6) Leki $\mathrm{Rx}$ - leki wydawane z przepisu lekarza.

7) Technika druku w celu uszlachetnienia, ozdobienia opakowania, z użyciem folii hot-stampingowej i matryc wypukłych wykonanych $\mathrm{z}$ materiału przewodzącego ciepło.

\section{Bibliografia}

[1] Bielski I. (2000), Przebieg i uwarunkowania procesów innowacyjnych, Oficyna Wydawnicza OPO, Bydgoszcz.

[2] Eurostat (online data code: inn_cis9_type), data dostępu: 20.01.2020 r.

[3] GUS (2014), Działalność innowacyjna przedsiębiorstw w latach 2011-2013, Informacje i opracowania statystyczne, Główny Urząd Statystyczny w Szczecinie.

[4] GUS (2019), Działalność innowacyjna przedsiębiorstw w Polsce w latach 2016-2018, Informacje sygnalne $\mathrm{z}$ dn. 28.10.2019 r., Urząd Statystyczny w Szczecinie.

[5] Gust-Bardon N.I. (2011), Polityka innowacyjna $w$ Polsce, „Ekonomia XLII - Nauki Humanistyczno-Społeczne”, Nr 402, s. $217-228$

[6] http://kbpoz.gs1.pl/, data dostępu: $21.01 .2020 \mathrm{r}$.

[7] http://www.newsline.pl/naukapublicrelations/slownikpojec/ art14.html, data dostępu: $15.01 .2020 \mathrm{r}$.
[8] GIS (2020), https://rejestrzp.gis.gov.pl/index.php/przegladaj/2008/169, data dostępu: 22.01.2020 r.

[9] Jarosz M. (2008), Suplementy diety a zdrowie. Porady lekarzy $i$ dietetyków, Wydawnictwo Lekarskie PZWL, Warszawa.

[10] Jasiński A.H. (1992), Przedsiębiorstwo innowacyjne na rynku, KiW, Warszawa.

[11] Kaczmarska B. (2017), Ocena poziomu innowacyjności przedsiębiorstw na podstawie zasobów internetowych, ptzp.org.pl, data dostępu: 15.07.2017 r.

[12] Knosala R., Boratyńska-Sala A., Jurczyk-Bunkowska M. i in. (2014), Zarzadzanie innowacjami, PWE, Warszawa.

[13] Komunikat Komisji Europa 2020 (2010), Strategia Europa 2020, Strategia na rzecz inteligentnego i zrównoważonego rozwoju sprzyjającego właczeniu społecznemu, Bruksela.

[14] Malara Z., Hrydziuszko M., Ziembicki P. (2015), Innowacyjne modele biznesowe szansą na rozwój przedsiębiorstw, [w:] I. Dudzik-Lewicka, H. Howaniec, W. Waszkielewicz (red.), Zarzadzanie wiedza $i$ innowacje $w$ organizacji, Akademia Techniczno-Humanistyczna w Bielsku-Białej, Bielsko-Biała, s. 9-22.

[15] Motyka S. (2011), Pomiar innowacyjności przedsiębiorstwa, [w:] R. Knosala (red.), Komputerowo zintegrowane zarzadzanie, Oficyna Wydawnicza PTZP, Opole, s. 160-168.

[16] Nowak P. (2012), Poziom innowacyjności polskiej gospodarki na tle krajów UE, „Prace Komisji Geografii Przemysłu”, Nr 19, s. $153-168$.

[17] OECD (2005), Oslo Manual. Guidelines for Collecting and Interpreting Innovation Data, https://www.oecd -ilibrary.org/docserver/9789264013100-en.pdf?expi res $=1592586786 \& \mathrm{id}=\mathrm{id} \&$ accname $=$ guest $\&$ checksum $=8$ B54BF3A354CF41A1BDB5FA93990919C, access date: 19.06.2018.

[18] OECD (2018), Oslo Manual 2018. Guidelines for Collecting, Reporting and Using Data on Innovation, https://www.oecd. org/science/oslo-manual-2018-9789264304604-en.htm, access date: 18.01.2020.

[19] PARP (2019), Monitoring innowacyjności polskich przedsiębiorstw, Warszawa.

[20] Piekut M. (2011), Innowacyjność przedsiębiorstw w Polsce $i w$ innych krajach europejskich, Zeszyty Naukowe Małopolskiej Wyższej Szkoły Ekonomicznej w Tarnowie, Prace z Zakresu Zarządzania, Zarządzanie przedsiębiorstwem, Nr 2(19), s. $87-88$.

[21] PMR Industry Report (2019), Rynek suplementów diety w Polsce 2019. Analiza rynku i prognozy rozwoju na lata 2019-2024, PMR, Warszawa.

[22] Pomykalski A. (2001), Innowacje, Wydawnictwo Politechniki Łódzkiej, Łódź.

[23] Stankiewicz W. (2012), Rozwój gospodarki Unii Europejskiej - Strategia Lizbońska a nowy plan „Europa 2020”, „Rocznik Integracji Europejskiej”, Nr 6, s. 269-287.

[24] SW Research (2007), Polacy a suplementy diety, Agencja Badań Rynku i Opinii SW Research, Warszawa.

[25] Szwajca D. (2011), Dylematy pomiaru innowacyjności przedsiębiorstw, „Zarządzanie i Edukacja”, Nr 78, s. 61-76.

[26] Urząd Komitetu Integracji Europejskiej (2002), Strategia Lizbońska - droga do sukcesu zjednoczonej Europy, Wyd. I, Warszawa.

[27] Ustawa z dnia 25 sierpnia 2006 r. o bezpieczeństwie żywności i żywienia, Dz.U. z 2015 r., poz. 594, 1893. 


\section{Innovativeness of Polish Enterprises on the Dietary Supplements Market in Poland in the Context of the Europe 2020 strategy}

\section{Summary}

The article contains the analysis and assessment of innovativeness of dietary supplements producers in Poland with reference to the main assumptions of the European Union's policy included in the Europe 2020 strategy. The authors present in it strategies for innovation implemented in the European Union's countries and analyse criteria for benchmarking and assessing the level of enterprise innovation. According to the Oslo methodology, it has been assumed that a company is innovative if it has implemented at least one product, process, marketing or organisational innovation over a three-year period (in the years: 2016-2018). The indicator of the share of innovative enterprises in the general population and the aggregate index, called the Innovation indicator, have been used to evaluate the innovative activity of the entities. The authors have also analysed indirect indicators of innovation activity: research and development, cooperation with science, implementation of EU projects. The research covered 26 enterprises with dominant Polish capital, operating in the dietary supplement segment. The data was obtained as a result of surveys conducted in October 2019 - December 2019 and complemented by media monitoring (clipping technique). Based on the original Innovation indicator, $46 \%$ of the surveyed entities should be classified as strong innovators, $4 \%$ are innovation leaders. High percentage $(35 \%)$ is attributed to moderate innovators and poor innovators is a group of $15 \%$ of companies. In 2016-2018, 85\% of enterprises implemented product innovation, $77 \%$ - marketing innovation, $69 \%$ - process innovation and $54 \%$ - organisational innovation. As many as $69 \%$ of entities carried out research and development activities, and $62 \%$ of enterprises started cooperation with science. Half of the surveyed enterprises have obtained financial support from EU programs for the implementation of innovative projects.

\section{Keywords}

innovation, Innovation indicator, dietary supplements, pharmaceutical market 